\title{
Linguistic Interpretation of Proverbs in the Kenyang Language
}

\author{
Mbu Martha Njui \\ Department of English Language and Literature of English Expressions, Higher Teachers Training College, University \\ of Maroua, Cameroon
}

\begin{abstract}
Much has been written in the Kenyang language as far as descriptive grammar is concern, but there is still a lot to be done concerning its vocabulary and semantic analysis. Thus, this paper aims to analyze and explain the linguistic features that the Kenyang proverbs process. It equally seeks to discuss the functions and uses of proverbs taking examples from the language in question. The findings demonstrate that the Kenyang proverbs are characterized by linguistic features such as, metaphors, ironies and ellipses. The main functions of the Kenyang proverbs are to criticize, advice, warn and to give moral lesson to the hearers. Kenyang is a language spoken in the South West region of Cameroon precisely by the people of Manyu division.
\end{abstract}

Index Terms - proverbs, functions and uses, speakers intended meaning, irony, Metaphor

\section{INTRODUCTION}

According to the Oxford dictionary, the word "proverb is from a Latin word "pro-verbium" ("pro" meaning "in front of" and "Verbium" meaning "word"). This suggests that proverbs can take the place of ordinary words. However its study has received little attention up to now." (Fergusson, 2000: 137-138), says that, every culture and language has their own proverbs, which belong to the popular culture and tradition of their language. There are proverbs dating from ancient history such as "while there is life, there is hope." (Fergusson, 2000: 137-138). We also have sayings such as "An apple a day keeps the Doctor away". (Fergusson, 2000:131). Some of them became an important part of the society. Consequently, there are several origins of proverbs .But in spite of their different beginnings, many proverbs still belong to the current oral tradition and they are well known in modern society.

The fact that proverbs belong to oral tradition makes the task of finding when they were first used difficult. Before they were recorded in written forms for instance, introduced in literature or included in a document, they were already well-known in oral tradition. Since they spread by words of mouth from generation to generation, it is very difficult to know exactly when they first came out or their initial forms were. For example the proverb "Adversity makes strange beds fellows"( Fergusson, 2006:2) was first recorded by Shakespeare in The Tempest (1611).

(Gibbs, 1994), However, argues that until very recently, proverbs had not been addressed from a linguistic point of view. In the same line of thinking, Gibbs, Strom, and Spivey-Knowlton, (1997.) also discussed about the metaphorical nature of proverbs and its influence on the mental images of proverbs in the people's minds. . (Bock and Brewer, 1978) are other works that discussed how the figurative and literal meanings of the proverbs interacted in people's minds to produce an accurate and proper interpretation. (Ayeni, 2011, Odebunmi, 2008), had also tried to look at the pragmatic function of proverbs in specific instances of literature from different cultures.

Olabode B.O and Siyanbola S.O (2013:56) says that in a traditional and modern African society proverbs are generally accepted as the quintessence in the passage and communication of ideas and ethics among both old and the young. In fact, a scenario is best explained where a speaker encapsulate his thoughts in a suitable and appropriate proverb. Thus the saying, proverbs are palm oil with which words are eaten (Achebe, Chinua, Things Fall Apart p. 25). Hussein ( 2005:18) underscores the point made above when he observes that , Africa is a continent known for its rich oral arts and that proverbs are the most widely used in the continent', long tradition for oral arts . (Hussein, 2005: 19) argues that proverbs do not play any aesthetic role; they serve as the acceptable means of passing or transmitting knowledge and conversation from generation to generation. The Kenyang speakers give value to their proverbs they are used in every day's conversation, especially among the elders. The Kenyang people who are the speakers of the language in question are from Manyu division in the South West region of Cameroon. The cultural richness and diversity of the Kenyang people is gained through the love for their culture and language. Using proverbs is therefore a way of cultivating morals and other cultural values in the speakers. Consequently, the purpose of the present study is to give a linguistic interpretation of some linguistic features used in Kenyang proverbs. This is done by showing how Irony, Metaphors and Ellipsis are used in the Kenyang proverbs, and how they affect recognition, interpretation and understanding of proverbs in the Kenyang language. We have done this by dividing our work into four parts. Part one handles the introduction, while, part two focuses on data presentation and discussion. Part three dowels on the findings and results and finally part $\mathrm{V}$ is the conclusion. 
The data for this research article was collected through verbal discussions with some native speakers of the language. Mosts of these proverbs were analyses according to the context in which they are used. Each proverb was first taken in the kenyang language, then a word for word translation was given to enable the understanding of the various components of the sentence, and finally a literal translation was given in the English language to enable non native speakers understand the meaning of the proverb. It also draws inspiration from my personal contribution since am one of the speakers of the language in question. The (IPA) International Phonetic Alphabet was used as the bases for transcription.

\section{FUNCTIONS OF PROVERBS}

According to Ramirez, (2018) proverbs can be defined as a way of saying something implicitly rather than explicitly supporting your arguments in popular wisdom. She further added that, proverbs are considered part of the figurative language because; they are an indirect way of giving a set of assumptions about a shared thought between the hearer and speaker rather than directly stating them. The purpose of popular wisdom to her can be attributed to a wide range of topics that is different and that are other instances of proverbs expressing popular wisdom without any intention against the hearer such as the proverbs related to weather, as month of the year.

Hence, we are going to analyze the three main categories involved in proverb's intension they are: criticism, advice, and warning beside these three, we are also going to discuss the moral values of the Kenyang proverbs.

1) criticisms

As earlier mentioned, most at times a speaker writes a proverb and he or she has the aim of criticizing the hearer or making an accusation against him or her.

We can fine this in the following proverbs,

nsÏànsïà aâ kwáàn chïà nápÏÄò aà puà kwán baàkwaò

elder s.m fall cop colanut s.m neg fall plum

"An old man can only fall from a cola nut tree and not from a plum tree"

Meaning: there is an age for everything. There is an age where a man is supposed to behave and reason like an elder. If he fails to do so, he is made to reason through this proverb. In other words it is an indirect way of criticizing someone who refuses to reason or act according to his age.

Móñkwán aà puà kwán áchÏàkÏà mbinyoàp ndóñ epay

Child s.m neg fall step door time two

"A child does not fall on the same door step twice"

Meaning: you are not supposed to be a victim of the same crime more than once. It is also another way of telling someone that they are not wise because of the fact that they have become a victim of a particular situation more than once. Let us look at another example

móndaàk raàraà nyuò toàrïà

Small matter tinny mouth long

"A small problem that is neglected will always grow big"

"Meaning: It is always advisable to solve problems when they are at the beginning"

By using a proverb, the speaker is able to criticize the hearer, but the hearer cannot be annoyed with him, some proverbs rely on Implicate communication that the speaker expresses himself or herself. Looking at one of the aims of proverbs is veiling [odebunmi, 2008/7], that is, the speaker gives his/her opinions but expects the hearer to get his/her critical intension without offending him/her.

Lastly, criticism as a function of proverb helps to emphases the shared ideas and opinion rather than an offense to the hearer. What is more the used of proverbs and the ironic tone they usually carryout is seen minimized by their popular knowledge. And most of the time they are recognized by the hearer makes their ironic and critical tone less aggressive. Therefore the satirist, humoristic and joking character of proverbs, as well as in irony help us to communicate.

\section{2) Advice and warning}

These are other functions of proverbs whose aims are not to criticized but to give advice or enhance the hearer to do something. Let us look at the examples below

baà póòkóò átóòk chïà náñïlö̀̈ò páâ chïà aò ntiià

S.m carry town/village cop soldier neg s.m head

"We can only carry a village on the soldier and not on the head"

Meaning: Matters concerning the people or community are not supposed to be taken personal. This is an advice to a leader who forgets the fact that he has some limits as far as exercising power is concerned.

Káà cháà muò manyáò aà ñuà

S.m give man advice s.m die

"Don't give advice to kill a man"

This means that It is better not to give somebody advice than to advice them wrongly. It is dangerous giving a wrong advice to someone.

Moñkwán ò káò Äòoà aà puà róòp moñkañ moñkañ

Child neg grow s.m remain small small

"A child that does not grow will always remain a baby" 
Meaning: behaving less than your age mates always make you a baby.

Apart from these proverbs for advice, there are proverbs of warning whose goal is to warn us to prevent the hearer from doing something. Example

Nkóòk baà tuà aàÄòoàk nóòkóò chïà amáòm eteòj

Hen ear sm hear prg sm in pot

"A hen that does not listen to advice will always fine itself in a pot"

This proverb takes the form of an advice and warning at the same time. It is warning the hearer against stubbornness and waywardness and its consequences. This utterance is not only mere piece of advice but also a traditional speech. Consequently, proverbs are not only mental representations of once speech, but become a public representation in a given speech community.

The repeated transmission and representations create a chain of mental and public representations casually linked by a culture [sperber 1994.54]

\section{FINDINGS AND DISCUSSIONS}

\section{Linguistic Interpretation of the Kenyang proverbs}

We have discussed three main linguistic features that are found in the Keyang proverbs and we have equally shown how they help in their understanding.

\section{1) Irony and the Kenyang proverbs}

Besides the functions of the Kenyang proverbs described above, they also convey an ironic interpretation and tone, such as the example bellow.

Baà sóòt ndán pápáp ba gwáòt aà nñuà aà koàk

They take dress white sm tie sm mouth sm pig

"They have taken a white dress and tied around the pigs mouth"

The pig is use here as an imagery referring to man. Normally in the African tradition, pigs are known to be dirty animals. So it becomes ironical to give a white dress to the pig because it will not know its use. This proverb means that no matter how you take care of a dirty person he will still remain dirty. This is a very clear example of a critical proverb whose explicit rather than Implicit way. Therefore, as sperber and Wilson [1995] claim, ironic statements allow the speaker to express his/her own attitude in terms of the thought echoed or communicated through an ironic utterance.

Because of the ironic tone underplaying most proverbs, we apply this feature of irony so that the echoed attitude makes the recognition of the speaker's intension easier for him/her, to reach the right interpretative of the proverb. Example according to sperber and Wilson (2006:10) the aim of irony is to dissociate the speaker from an attributed thought as utterance which she wants to suggest is more or less of false, irrelevant or under informative, it is my belief that we can apply this to proverbs whose aim is to distract the hearer from their literal Meaning by offering him/her a second meaning given by the familiarity they carry out.

However, the communication of shared thoughts between a speaker and a hearer will be attributed to more factors such as; the implicit attitude of the speaker, the tone of voice, context or other linguistic parameters [sperber and Wilson, 1995.239] verbal irony is achieved through the correct use and interpretation of non verbal and contextual signs; in other word, paralinguistic elements. Actually proverbs intension is made through the tone of voice. [that is] making some sounds longer as emphasizing some specific parts of the proverbs; gestures such as smiling or moving the eyes or body language as pointing to someone or knocking your head. For example

wóà puà naà náchïà nkóòk ó òká waòj nóò

you neg cook egg cock neg kill it

"You cannot make an omelet without breaking the egg"

We tend to make longer the sound of the first part with a knock of the head to make the hearer recognize of our ironical intension.

\section{2) Metaphors and the kenyang proverbs}

Furthermore, as a piece of figurative language, proverbs may also have a metaphoric, intension sometimes Richards describes metaphors as a combination of two routs; topic usually the subject of the metaphorical sentence and the vehicle the tern used metaphorical [Bock and Brever, 1978.60 quoted from Richards, 1965].The relationship of similarity between the topic and the vehicle is the key to understand a metaphors [Bock and Brewer, 1978.60]. In this sense, I think we can consider proverbs as metaphors in which only the vehicle - the term used metaphorically- is explicitly stated, but topic-subject of the metaphor-is left implicit [Bock and Brezer, 1978.60 quoted from per 1971]

Furthermore, there is no division line between the literal and metaphorical meaning or between the ironical utterances and their echoic situations, but a continuum of cases ranging from what the subject of the proverb is to how it is expressed. (Sperber \&Wilson 1995:243) say that whereas "metaphors plays on the relationship between the propositional form of an utterance and the speaker thought, irony plays on the relationship between the speaker's thought and a thought of someone other than the speaker". Below are some examples of some proverbs that use metaphors in Kenyand. 
móò náò ó chïà máòn

child this is goat

"This child is a goat/sheep"

móò náò ó chïà ñkóòk

child this is hen

"This child is a hen"

móò náò ó chïà aàkoàk

child this is hen

"This child is a pig"

From the examples above, it is seen that the metaphors in Kenyang language are mostly use to compare that is comparing humans to animals

3) Ellipses and the Kenyang Proverbs

Sometimes, it is not necessary to fully utter the proverb for it to be understood. In fact, there are many examples in which just the former part of the proverb is uttered, omitting the last part, since the speaker consider the hearer would recognized the beginning of the proverb. Making thus the stimulus the most relevant one he could chose. For example the proverb

Wóò ßÏ̀̀ kòìa tóòk bá chïà ... “if you don’t touch bitter leaf ...” That as soon as the hearer processes the first part of the proverb he/s can anticipate the following aà móò yïà aà puà náòn " his hands will not be bitter" .This might be attributed to the fact that many Kenyang proverbs are so frequently used and so highly familiar that just with the uttering part of it, the hearer will be able to interpret the piece of popular wisdom intended by the speaker, being thus an efficient way of communicating as it is of shared assumptions in the form of cultural knowledge(yus, 2009:317) Due to the frequent use, the given information and the contextual knowledge lead the hearer to recover the rest of the proverb implicitly. In other words, it is indispensable to utter the proverb in a full form to be able to reach the right interpretation.

The aim of ellipses in the Kenyang proverbs is to economize the process involved in proverb recognition and interpretation. The fact that we always omit the second part of the proverb is because in familiar proverbs, just the first part is enough to recognized proverbs intension and therefore it is more economical for the hearer to process just part of it instead of the whole proverb.

Proverbs in Africa are used to guide the behavior of growing children and to help them to mold their characters. Proverbs deal with knowledge, experience, hard work, and human relations. We believe that a study of language and proverbs can help students understand other cultures.

Olabode and Siyanbola (2013) say that the relevance of these proverbs are demonstrated by such sayings as "A proverb is the horse of conversation: when the conversation lags, a proverb will revive it"; "A wise man who knows proverbs reconciles difficulties (Yoruba, Nigeria); and "Proverbs are the daughters of experience" (Sierra Leone).

Kenyang proverbs provide hard hitting messages in a profound way rather than a nasty or demoralizing manner and at times even acts as an advice to the community. .For example

1) Nkók baàtuà aâ Äoàk nókó mbañ a mem átaj noòk

Hen ear s.m hear prog time s.m in pot soup

"A stubborn hen always listens in the pot of soup."

This is to say that any one that does not listen to advice will always find themselves in problems. This is another way of advising the people to always seek to advice before acting.

The Kenyang speakers give a lot of preference to proverbs because for them, proverbs are the easiest way in which the elders use to send a message through. ( Lawal, 1997:637 ) beliefs that , if young people must resort to use of proverbs, they must defer to the elders let's look at some examples :

2) Mókwán aà ná aà soà aàmóò yï̀n, aâ nányá ne baà fó

Child s.m that s.m wash hands his s.m eat with s.m chief

"A child that washes his hands eats with the chieves"

Here we are not talking about the physical washing of hands but is a metaphor which means behavior or morals. , In other words, this proverb suggests that if a child behaves well, he will sit in the presence of the elders or gets the admiration of the elders.

The second Kenyang proverb that explains that the fact that old people are holders or a warehouse were proverbs are stored is

3) áyİ̃ná ná nsÏniè aà Äóò tSóàkóà, mókwán aà ná aà chïà aò faòj taàmaàñaà aà puà Äóò

thing that old man s.m see sit child s.m that is s.m up coconut s.m neg see

"What an old man sits and see, a young man on top of a coconut tree can never see it"

This means that, the elders are full of experiences that the young people need not wrestle with them as far as ideas and experiences are concern. 
4) Ákát á puà sóñó ná ba nsïâsïà tSóàkóà,

House s.m neg burn with elders sit

"The roof must not get burnt with elders in it".

This means that, matters must not get out of hand where an elder is present. The latter part of the proverb is usually uttered as permission, the elders present will reply, 'Yes". According to Lawal, (1997; 637), Proverbs are used to show and sustain respect for elders. In a summary, The Kenyang proverbs emerged or evolved from traditional, socio-cultural, philosophical and cosmological belief systems.

The aesthetic functions of the Kenyang proverbs have made them indispensable in oral artistry. This is seen in (Ojoade, 2001) when he says, proverbs are the analytic tools of thought, when thought is lost; it is proverbs that are used to fetch it.

\section{CONCLUSION}

We set out to discuss and analyse the linguistic features that the kenyang proverbs contain, and we discovered that they are that part of language that represent and link the people to their culture. We also discussed the Metaphorical and ironical nature of the Kenyang proverbs and we came out with the conclusion that, they help the hearer to recognize and identifier himself with his community and how in the interpretation and understanding of proverbs. We equally asserted that criticism, advice and warning are the main function of proverbs beside the fact that they have an underlying moral tone. Also important is the fact that people also consider the advantage of the implicit criticism they usually express to avoid the annoyance of the hearer, besides we highlighted other minor functions of the Kenyang proverbs such as giving moral instructions.

\section{REFERENCES}

[1] Abang, P.B.A.M. Functions and uses of the Sarawak proverbs published online sourcer:https://www.shs-conference.org.article.

[2] Abumere, S. (1987). "Urbanization and Urban Decay in Nigeria" in Onibokun, A.G, Olokekusi, Femi and Egunjobi Layi (eds).Urban Renewal in Nigeria. NISER/CURP, Ibadan.

[3] Achebe, C. (1958). Things Fall Apart. London: Heinemann.

[4] Agbola, Tunde and A.O. Mabawonku. (1996). Indigenous Knowledge, Environmental.

[5] Education Ajolore, O. (1982). "Lexical Borrowing in Yoruba". In Afolayan, A. (ed.) Yoruba Language and Literature, Ibadan: University Press Ltd, pp. 145-164

[6] Anne, R. (2010). Therelevance of Relevance for fiction, Behavioral and Brain science publish online: https://wwwCombridge.org/core/jourals/behavioral-and-brain -science/article.

[7] Ayeni Gholahan Olusoji. (2011). Pragmatic analysis of Nigerian Proverbs in Whole Soyinka's The lion and the Jowel. Department of English, Faculty of Arts, University of Ilorin, Ilorin, Nigeria.

[8] Bock, Kathryn J. and Brewer, William F. (1980). Comprehension and memory of the Herald and Figurative meaning of proverbs in Journal of Psycho linguistics Research.vol.9Nu 980. 59-72 https://pdfs.semanticscholar.org/.

[9] Brayan , Gregory A. and FoxTree Jean E. (2002). Recognizing Verbal Irony in Spontaneous Speech, Metaphors and Symbols, 17 2, 99-117 online publication :https:// www.tandfonline. Com/doi/ abs/10.1207/S153278668msi702-3.

[10] Brayan, Gregory A. (2012). Is Verbal Irony Special? Language and linguistic Compass 6/11,673-685online publication: https://online library.wiley.com/doi.abs/1o.1002/Inc3.364.

[11] Chapin, S. Jr. (1957). Urban Land Use Planning, Hamper and Brothers, New York, Especially Pp.232-233. Published online: journals.sagepub.com.

[12] Falola, Toyin. (2007). "Nationalising Africa, Culturalising the West, and Reformulating the Humanities in Africa". In Akinriande, S. Fashina, D.Ogungbile, D. \& Famakinwa, J. (eds). Rethinking Humanities in Africa, edited by Ile-Ife, Department of African Languages and Literatures, University of Ife, pp.89-114.

[13] Fergusson, RAOSALIND. (2000). The Punquin Dictionary of Proverbs. Market House books Ltd 2nd edition, England.

[14] Gibbs, Raymond W. (1994). the poetics of the mind, figurative thought, language of the mind and understanding, Cambridge University press. Online publication: https://scienceblogs Com/miximgmempry/2007/06/18.

[15] Gibbs, Raymond W. JR Strom, Lise K Spivey-Knowlton, Michael J. ( 1997). Conceptual Metaphors in Mental Imagery for Proverbs in: Journal of mental imagery 1997, 21 (3\&4) Akhter Ashen, Brandon House. 83-110.

[16] Finnegan, Ruth. (1970). Oral Literature in Africa. Oxford: Clarendon Pres

[17] Foster, LM, Osunwole, M; Samuel A, and Wahab W. (1996). Imototo: Indigenous Yoruba Sanitation Knowledge Systems and their Implications for Nigerian Health Policy, in Frank Fairfax III. Bolanle Wahab, Layi Egunjobi and D. Michael Warren (eds.). Alafia and Well-Beingin Nigerian Studies. In Technology and Social Change, No. 25 Ames Centre for Indigenous Knowledge for Agriculture and Rural Development, IOWA University.

[18] Hussein J.W. (2005). The Social and Ethno-cultural Construction of Masculinity and Femininity in African Proverbs. 59 African Study Monographs, 26 (2): 59-87.Kehinde, Ayo (2004): "Proverbs as Thematic Vehicle in Recent African Short Fiction". Proverbium. 21:119-136.published online:https://www.allbest.ru/.

[19] https://verinigafrica.wordpress.com.

[20] https://wwwphon.ucl.ac.uk.

[21] Lawal, R.A (1997). Aspects of a Pragmatic Theory. Unpublished Monograph. Institute of Education, University of Ilorin.

[22] Lawal, R.A, Bade Ajayi \& Wumi Raji. (1997). 'A Pragmatic Study of Selected Pairs of Yoruba Proverbs'. In Journal of Pragmatics 263652.Onlinesourse:https://wwwsciencedirect.com /science/article/pli/pdf. 
[23] Martin Gary. (1996-2015). Meaning and Origins. in The phrase finders. Online Researchers http./www.phrases.org.uk/Meanings/ proverbs. Html [Last visited: 13th June 2015].

[24] Odebunmi, Akin. (2008). Pragmatic functions of Crisis -Motivated proverbs in Ola Rotimis The Gods are not to blame Linguistik online 331 1/2008 https://bop.unibe.ch/linguistik-online.article /view 530.

[25] Oduyale, O. (1985). Traditional Education in Nigeria. Pp 230-244. In O.Y. Oyeneye and O.M Shoremi (eds.). Nigerian Life and Culture. Ago Iwoye; Ogun State University.

[26] Ojo-ade, T. (2001). Internationalism Rooted in Proverbs, Proverbs: Roots of Internationalism, os: Uni. Jos Consultancy Ltd.

[27] Olabode B. O and asayanbola S.O. (2013). Proverbs and Taboos as Panacea to environmental problems in Nigeria a case of selected Yoruba proverbs. in Journal of Arts and Contemporary Society .vol 5, no2 pp:56-66 published on line: https//cenresinpub.files.wordpress.com.

[28] Oxford Learners dictionary. (2015). Oxford University press. Online resource: https://www.oxfordlearners dictionary .com/Definition/english.proverbs/q=proverbs.

[29] Parrinder, G. (1969). West African Religion. London: Epworth Press.

[30] Sperber, Dan. (994). The Modularity of the thought and the Epidemiology of representations in Mapping the Mind: Domain Specificity in cognition and Cultural, Laurence Hirschfeild and Susan German eds, Cambridge press, 39-66. Online publication: www.dan. Sperba.fr/content/upload/1994.-.

[31] Sperber, Dan and Wilson, Deirdre. (1995). Relevance -Communication and Cognition [2nd edition] Blackwell, Oxford UK \& Cambridge USa Online publication: www.dan.sperba. .fr/wp-content/upload/1987-wilson-precis-of-relevance pdf.

[32] Sperber, Dan \& Hirschfeld, Lawrence. (2007). Cultural and Modularity in: Tom Samson, Peter Caruthers, Stephen Lawrence and Stephen Stich, The innate Mind: Cultural and Cognition Oxford: O.U.P, 149-677.

[33] Ramirez, H.C. (2015). Pragmatic approach to proverb use and interpretation online Source: https://prezi.com./n8hm]lozmyly/

[34] Rodin.uca.es.

Mbu M. Njui was born in Kumba, Cameroon in 1976. She obtained a PhD in linguistics from the University of Yaoundé 1 Cameroon in 2016.

She is currently a Senior lecturer at the Higher Teachers Training College University of Maroua Cameroon. Her research interest includes general and African linguistics.

Dr Njui is a member of the Association of female lecturers, University of Maroua. 